\title{
Eudraginated polymer blends: A potential oral controlled drug delivery system for theophylline
}

\author{
MARTINS EMEJE ${ }^{1 *}$ \\ LUCY JOHN-AFRICA ${ }^{2}$ \\ YETUNDE ISIMI ${ }^{1}$ \\ OLOBAYO KUNLE \\ SABINUS OFOEFULE 3 \\ ${ }^{1}$ Department of Pharmaceutical \\ Technology and Raw Materials \\ Development, National Institute \\ for Pharmaceutical Research and \\ Development (NIPRD), Abuja, Nigeria \\ 2 Department of Pharmacology and \\ Toxicology, National Institute for \\ Pharmaceutical Research and Development \\ (NIPRD), Abuja, Nigeria
}

${ }^{3}$ Department of Pharmaceutical Technology and Industrial Pharmacy University of Nigeria, Nsukka Enugu state, Nigeria

Accepted November 28, 2011

\begin{abstract}
Sustained release (SR) dosage forms enable prolonged and continuous deposition of the drug in the gastrointestinal (GI) tract and improve the bioavailability of medications characterized by a narrow absorption window. In this study, a new strategy is proposed for the development of SR dosage forms for theophylline (TPH). Design of the delivery system was based on a sustained release formulation, with a modified coating technique and swelling features aimed to extend the release time of the drug. Different polymers, such as Carbopol 71G (CP), sodium carboxymethylcellulose (SCMC), ethylcellulose (EC) and their combinations were tried. Prepared matrix tablets were coated with a $5 \%(\mathrm{~m} / \mathrm{m})$ dispersion of Eudragit (EUD) in order to get the desired sustained release profile over a period of $24 \mathrm{~h}$. Various formulations were evaluated for micromeritic properties, drug concentration and in vitro drug release. It was found that the in vitro drug release rate decreased with increasing the amount of polymer. Coating with EUD resulted in a significant lag phase in the first two hours of dissolution in the acidic $\mathrm{pH}$ of simulated gastric fluid (SGF) due to decreased water uptake, and hence decreased driving force for drug release. Release became faster in the alkaline $\mathrm{pH}$ of simulated intestinal fluid (SIF) owing to increased solubility of both the coating and matrixing agents. The optimized formulation was subjected to in vivo studies in rabbits and the pharmacokinetic parameters of developed formulations were compared with the commercial (Asmanyl ${ }^{\circledR}$ ) formulation. Asmanyl ${ }^{\circledR}$ tablets showed faster absorption $\left(t_{\max }\right.$ $4.0 \mathrm{~h}$ ) compared to the TPH formulation showing a $t_{\max }$ value of $8.0 \mathrm{~h}$. The $C_{\max }$ and $A U C$ values of TPH formulation were significantly $(p<0.05)$ higher than those for Asmanyl ${ }^{\circledR}$, revealing relative bioavailability of about $136.93 \%$. Our study demonstrated the potential usefulness of eudraginated polymers for the oral delivery of the sparingly soluble drug theophylline.
\end{abstract}

Keywords: theophylline, polymer blends, modified release, in vitro release, in vivo release

* Correspondence; e-mail: martinsemeje@yahoo.com 
When polymers of varying physicochemical properties are blended, they do not interact in the same way with water and drug molecules, resulting in different mobility of water and drug within the polymeric networks (1-4). Polymer blends sensitive to the surrounding environment may be of particular interest for many applications (5-7).

The use of Carbopols in drug delivery, especially in sustained release formulations, may sometimes require other additives because of the high drug release retardant effect encountered with the polymer $(7,8)$. These additives are capable of interacting with the polymer to attenuate release of the incorporated active drug $(7,8)$. Theophylline, an alkaloid found in the leaves of Camellia sinensis is used clinically as a bronchodilator in the management of chronic obstructive pulmonary disease (9). Theophylline therapy of airways obstruction, associated with asthma and chronic bronchitis, with conventional immediate release regimen tablets or solutions requires treatment every six hours due to the short half-life of theophylline in the body and its narrow therapeutic index, with 5-20 $\mu \mathrm{g} \mathrm{mL}^{-1}$ serum concentrations (9). Thus, sustained release dosage forms of theophylline can provide desirable serum concentrations for prolonged periods without frequent dosing, thereby providing patient compliance.

In this study, the effect of blending ethyl cellulose (EC) and sodium carboxymethylcellulose (SCMC) with Carbopol 71G at different ratios on the release profile of theophylline was investigated.

\section{EXPERIMENTAL}

\section{Materials}

Theophylline powder (TPH) and ethylcellulose (EC) (Sigma, UK), Eudragit 1-100 (Rohm Pharma, Italy), Emcocel ${ }^{\circledR} 50$ (microcrystalline cellulose, Penwest Pharmaceuticals, England), Carbopol 71G (Noveon, USA), sodium carboxymethyl cellulose (SCMC) (Wako, Japan) were used. All other chemicals were of analytical grade.

Asmanyl ${ }^{\circledR} 300$ SR tablet (Square Pharmaceuticals Ltd., Bangladesh) is a sustained release tablet containing theophylline BP $300 \mathrm{mg}$ in a sustained release formulation.

\section{Animals and in vivo studies on theophylline from optimized tablet matrices}

Adult male New Zealand white rabbits weighing 3.75-4.95 kg were used. They were kept at standard temperature $\left(26 \pm 1{ }^{\circ} \mathrm{C}\right), 12 \mathrm{~h}$ light/dark cycle, fed standard rodent feed and had free access to drinking water. The animals were fasted for $20 \mathrm{~h}$ before experiment. Experiments were started at the same time of the day and fasting was continued for the first $9 \mathrm{~h}$ of the experiment.

Approval was obtained from the institutional ethical board (IEB). Guidelines on the use of animals were observed in accordance with the »Principles of Laboratory Animal Care $\lll$ and institutional standard operating procedures.

Animals were divided into two groups of 5 animals each. Group one administered one tablet F15 each, while group two received one Asmany $1^{\circledR}$ tablet each. Blood samples were collected after 30 min via the ear artery, centrifuged, and the plasma drug concen- 
M. Emeje et al.: Eudraginated polymer blends: A potential oral controlled drug delivery system for theophylline, Acta Pharm. 62 (2012) 71-82.

tration was determined spectrophotometrically at $277 \mathrm{~nm}$ using a Shimadzu UV 160 A spectrophotometer (Shimadzu, Japan) (10). This was repeated at different time intervals over a period of $24 \mathrm{~h}$.

\section{Pharmacokinetic analysis}

Pharmacokinetic analysis was performed using a bioavailability Calc 2002 pharmacokinetic analysis computer program (Korea Food \& Drug Administration, Korea). Area under the curve $(A U C)$ was calculated using the linear trapezoidal rule. Maximum plasma concentration $\left(C_{\max }\right)$ and the time needed to reach the maximum plasma concentration $\left(t_{\max }\right)$ were determined directly from the concentration-time data. The elimination rate constant $\left(K_{\mathrm{el}}\right)$ was obtained from the terminal slope using regression analysis, and the half-life $\left(t_{1 / 2}\right)$ of the drug was calculated by a relationship of $0.693 / K_{\mathrm{el}}$. Relative bioavailability was calculated as percentage of the AUC of TPH formulations to Asmanyl ${ }^{\circledR}$ tablets.

\section{Preparation of theophylline granules and compressed matrices}

Wet granulated tablet formulation containing $33.3 \%$ theophylline, 10, 20 and $30 \%$ $(\mathrm{m} / \mathrm{m})$ of the various polymers and their binary blends in ratios of $1: 1,3: 1$, and 1:3, $1 \%$ magnesium stearate and Emcocel were prepared. The composition of different matrix tablets is given in Table I. The drug and each polymer were dispersed in $5 \mathrm{~mL}$ of hot water at $\leq 100{ }^{\circ} \mathrm{C}$. Dispersed polymer and drug were mixed thoroughly and then the required amount of diluent was added and thoroughly kneaded. The semi-liquid mix was extruded onto glass slides and dried in a hot air oven at $60^{\circ} \mathrm{C}$ for $24 \mathrm{~h}$. Dried rods were pulverized using a blender for $10 \mathrm{~min}$ passed through a sieve $(250 \mu \mathrm{m})$ and finally compressed into compacts at $27.5 \mathrm{kN}$, on a single punch tablet press (THP Shanghai, Tianxiang ad Chentai Pharmaceutical Machinery, China) equipped with a $10.5-\mathrm{mm}$ punch and die set. The prepared tablets were soaked in $5 \mathrm{~mL}(5 \%, \mathrm{~m} / \mathrm{m})$ aqueous dispersion of Eudragit l-100 for $24 \mathrm{~h}$. Swollen tablets were again dried at $60{ }^{\circ} \mathrm{C}$ for $24 \mathrm{~h}$. A total of eighteen batches of the matrix tablets with almost constant theoretical mass of $300 \mathrm{mg}$ were produced. Fifty tablets were made for each batch.

The bulk, tapped density, compressibility and angle of repose were determined using standard methods (11). Triplicate determinations for each parameter are reported.

\section{In vitro drug release}

Drug release study was carried out at $37 \pm 0.5^{\circ} \mathrm{C}$ using the USP (12) basket type dissolution test apparatus. The basket apparatus was used in order to reduce variability due to the hydrodynamic conditions of the test and to overcome the problem of possible sticking of the gelled matrix on the wall of the dissolution vessel. The study was performed using an Erweka DT 8 liter dissolutions rate tester (Erweka, Germany) at a speed of $100 \mathrm{rpm}$. A 900-mL volume of dissolution medium was used at varying $\mathrm{pH}$ to simulate the gastrointestinal $\mathrm{pH}$ variation; the simulation of gastrointestinal transit conditions was achieved by altering the $\mathrm{pH}$ of the dissolution medium at various time intervals. The $\mathrm{pH}$ of the dissolution medium was kept at 1.2 for $2 \mathrm{~h}$ with $0.1 \mathrm{~mol} \mathrm{~L}^{-1} \mathrm{HCl}$. 
M. Emeje et al.: Eudraginated polymer blends: A potential oral controlled drug delivery system for theophylline, Acta Pharm. 62 (2012) 71-82.

Table I. Composition of matrix tablets of theophylline

\begin{tabular}{ccccccc}
\hline Batch & $\begin{array}{c}\text { Theophylline } \\
(\mathrm{mg})\end{array}$ & C 71 (mg) & EC $(\mathrm{mg})$ & SCMC $(\mathrm{mg})$ & $\begin{array}{c}\text { Emcocel } \\
(\mathrm{mg})\end{array}$ & $\begin{array}{c}\text { Mg-stearate } \\
(\mathrm{mg})\end{array}$ \\
\hline F1 & 100 & 30 & 0 & 0 & 167 & 3.0 \\
F2 & 100 & 60 & 0 & 0 & 137 & 3.0 \\
F3 & 100 & 90 & 0 & 0 & 107 & 3.0 \\
F4 & 100 & 0 & 30 & 0 & 167 & 3.0 \\
F5 & 100 & 0 & 60 & 0 & 137 & 3.0 \\
F6 & 100 & 0 & 90 & 0 & 107 & 3.0 \\
F7 & 100 & 90 & 30 & 0 & 77 & 3.0 \\
F8 & 100 & 60 & 60 & 0 & 77 & 3.0 \\
F9 & 100 & 30 & 90 & 0 & 77 & 3.0 \\
F10 & 100 & 0 & 0 & 30 & 167 & 3.0 \\
F11 & 100 & 0 & 0 & 60 & 137 & 3.0 \\
F12 & 100 & 0 & 0 & 90 & 107 & 3.0 \\
F13 & 100 & 0 & 90 & 30 & 77 & 3.0 \\
F14 & 100 & 0 & 60 & 60 & 77 & 3.0 \\
F15 & 100 & 0 & 30 & 90 & 77 & 3.0 \\
F16 & 100 & 90 & 0 & 30 & 77 & 3.0 \\
F17 & 100 & 60 & 0 & 60 & 77 & 3.0 \\
F18 & 100 & 30 & 0 & 90 & 77 & 3.0 \\
\hline
\end{tabular}

C71 - Carbopol; EC - ethylcellulose; SCMC - sodium carboxymethylcellulose

Then, $0.01 \mathrm{~mol} \mathrm{~L}-1$ of $\mathrm{KH}_{2} \mathrm{PO}_{4}$ and $0.02 \mathrm{~mol} \mathrm{~L}-1 \mathrm{~g}$ of $\mathrm{Na}_{2} \mathrm{HPO}_{4} \times 2 \mathrm{H}_{2} \mathrm{O}$ were added, adjusting the $\mathrm{pH}$ to 6.8 by adding $1.0 \mathrm{~mol} \mathrm{~L}^{-1} \mathrm{NaOH}$. A release rate study was continued for another $3 \mathrm{~h}$. At preset time intervals, 5-mL aliquots were withdrawn using a pipette fitted with a micro filter and replaced immediately with an equal volume of fresh dissolution medium. The samples were analyzed spectrophotometrically at $272 \mathrm{~nm}$ using. The data presented are averages of triplicate determinations.

\section{RESULTS AND DISCUSSION}

\section{Micromeritic properties of granules}

The granules micromeritic properties are shown in Table II. Angle of repose ranged from 22.32 to $32.07^{\circ}$ indicating that all the granules had a reasonable flow potential. According to Staniforth (13), angles close to $25^{\circ}$ correspond to very good flow properties. Our results show that, apart from batches F2 (containing Carbopol alone), F6 (containing EC alone) and F16 (containing a blend of Carbopol and SCMC 3:1), all other batches showed very good flow. The binary combination of EC and Carbopol was observed to 
M. Emeje et al.: Eudraginated polymer blends: A potential oral controlled drug delivery system for theophylline, Acta Pharm. 62 (2012) 71-82.

improve the flow (F7 and F8). This may be attributed to the hydrophobic nature of EC which may adsorb water molecules usually associated with Carbopol formulations.

Compressibility index $(\mathrm{CI})$ is an indicator of changes that occur in the packing arrangement powder tapping, and is a direct measure of the propensity of a powder to consolidate while undergoing vibration, shipping and handling (13) Table II shows that the compressibility index was highest for batch F3 (containing $30 \%$ Carbopol) which expectedly had a low flow rate. However, blending Carbopol with EC (F7-F9) or SCMC (F16-F18) significantly $(p<0.05)$ reduced the CI values, implying that these polymer additives improved the flowability of Carbopol polymer. CI for the granules generally ranged from 11.6 to $24.6 \%$. This result shows that the incorporation of EC or SCMC into Carbopol matrices (F7-F9 and F16-F18) improved the flowability of the single polymer (F3). It has been reported (13) that powders with CI between 5 and $18 \%$ have satisfactory flowability. Results of the flow rate (FR) show that blending improves the flow of granules, as indicated by the FR values of batches F13, F17 and F18 compared to the batches containing single polymers (F1-F6 and F10-F12). The highest value for FR was obtained for batch F13 containing $30 \%$ EC, the hydrophobic component of that formulation. The high amount of EC in this formulation may have discouraged the take-up of

Table II. Micromeritic properties of theophylline granules

\begin{tabular}{ccccccc}
\hline Code & $\begin{array}{c}\text { Flow rate } \\
\left(\mathrm{g} \mathrm{s}^{-1}\right)^{\mathrm{a}, \mathrm{b}}\end{array}$ & $\begin{array}{c}\text { Bulk density } \\
\left(\mathrm{g} \mathrm{mL}^{-1}\right)^{\mathrm{a}, \mathrm{b}}\end{array}$ & $\begin{array}{c}\text { Tapped density } \\
\left(\mathrm{g} \mathrm{mL}^{-1}\right)^{\mathrm{a}, \mathrm{b}}\end{array}$ & $\begin{array}{c}\text { Angle of } \\
\text { repose }\left({ }^{\circ}\right)^{\mathrm{a}, \mathrm{c}}\end{array}$ & $\begin{array}{c}\text { Compressibility } \\
\text { index }(\%)\end{array}$ & $\begin{array}{c}\text { Hausners } \\
\text { quotient }\end{array}$ \\
\hline F1 & $0.54 \pm 0.10$ & $0.649 \pm 0.00$ & $0.758 \pm 0.01$ & $26.32 \pm 0.40$ & 14.4 & 1.17 \\
F2 & $0.72 \pm 0.01$ & $0.526 \pm 0.00$ & $0.667 \pm 0.00$ & $30.11 \pm 0.66$ & 21.4 & 1.27 \\
F3 & $0.39 \pm 0.60$ & $0.571 \pm 0.00$ & $0.714 \pm 0.00$ & $27.24 \pm 0.37$ & 24.6 & 1.33 \\
F4 & $0.65 \pm 0.02$ & $0.646 \pm 0.00$ & $0.811 \pm 0.00$ & $28.75 \pm 0.20$ & 20.4 & 1.26 \\
F5 & $1.09 \pm 0.02$ & $0.663 \pm 0.00$ & $0.777 \pm 0.00$ & $28.32 \pm 0.40$ & 14.7 & 1.17 \\
F6 & $1.07 \pm 0.00$ & $0.573 \pm 0.01$ & $0.709 \pm 0.01$ & $30.11 \pm 0.66$ & 19.2 & 1.24 \\
F7 & $0.79 \pm 0.00$ & $0.643 \pm 0.01$ & $0.785 \pm 0.01$ & $26.00 \pm 0.00$ & 18.1 & 1.30 \\
F8 & $0.72 \pm 0.00$ & $0.631 \pm 0.01$ & $0.761 \pm 0.00$ & $26.01 \pm 0.20$ & 17.1 & 1.22 \\
F9 & $0.83 \pm 0.01$ & $0.601 \pm 0.00$ & $0.713 \pm 0.00$ & $28.32 \pm 0.40$ & 15.7 & 1.21 \\
F10 & $0.53 \pm 0.00$ & $0.586 \pm 0.00$ & $0.725 \pm 0.01$ & $29.11 \pm 0.66$ & 19.2 & 1.19 \\
F11 & $0.77 \pm 0.01$ & $0.582 \pm 0.01$ & $0.730 \pm 0.01$ & $27.24 \pm 0.37$ & 20.3 & 1.24 \\
F12 & $0.47 \pm 0.03$ & $0.575 \pm 0.02$ & $0.717 \pm 0.00$ & $25.07 \pm 0.00$ & 19.8 & 1.25 \\
F13 & $2.67 \pm 0.03$ & $0.648 \pm 0.01$ & $0.758 \pm 0.01$ & $27.32 \pm 0.40$ & 14.5 & 1.25 \\
F14 & $1.04 \pm 0.01$ & $0.648 \pm 0.00$ & $0.733 \pm 0.01$ & $23.11 \pm 0.66$ & 11.6 & 1.09 \\
F15 & $0.30 \pm 0.00$ & $0.592 \pm 0.01$ & $0.778 \pm 0.00$ & $27.24 \pm 0.37$ & 23.9 & 1.17 \\
F16 & $0.43 \pm 0.00$ & $0.609 \pm 0.01$ & $0.789 \pm 0.01$ & $32.07 \pm 0.00$ & 22.8 & 1.13 \\
F17 & $1.16 \pm 0.05$ & $0.612 \pm 0.01$ & $0.721 \pm 0.01$ & $27.75 \pm 0.20$ & 15.1 & 1.31 \\
F18 & $1.47 \pm 0.00$ & $0.625 \pm 0.00$ & $0.750 \pm 0.01$ & $22.32 \pm 0.40$ & 16.7 & 1.30 \\
\hline
\end{tabular}

a Mean \pm SD (standard deviation).

b $n=5$

${ }^{c} n=3$ 
M. Emeje et al.: Eudraginated polymer blends: A potential oral controlled drug delivery system for theophylline, Acta Pharm. 62 (2012) 71-82.

moisture, thereby improving the flow. Flow rate rather than $\mathrm{CI}$ is a direct measure of powder flowability. Blending was generally, found to improve the micromeritic properties of the formulations.

The results for bulk and tapped densities ranged from 0.526 to $0.663 \mathrm{~g} \mathrm{~mL}^{-1}$ and 0.667 to $0.811 \mathrm{~g} \mathrm{~mL}^{-1}$, respectively. Bulk density depends primarily on the particle-size distribution, particle shape and the tendency of particles to adhere to one another (12).

\section{Tablet properties}

Drug content uniformity of the formulations ranged from 98.9 to $100.3 \%$, signifying that the tablets possessed satisfactory drug concentration uniformity of the different batches of tablets. The results of evaluation tests performed on the theophylline matrix tablets are tabulated in Table III. Mass uniformity of the tablets ranged from $300.0 \pm 1.3$ $\mathrm{mg}$ to $302.0 \pm 0.9 \mathrm{mg}$.

Results in Figs. 1a-c show the release pattern of theophylline from different batches of formulated matrix tablets containing Carbopol, ethylcellulose and sodium carboxymethyl cellulose, respectively. It is obvious that by increasing the concentration of the polymer from 10 to $30 \%(\mathrm{~m} / \mathrm{m})$ the release became slower. The extent of drug release retardation as measured by the time required for 50 and $70 \%$ of the drug to be released ( $t_{50}$ and $t_{70}$, respectively) was observed to be dependent on both the type and concentra-

Table III. Release properties of theophylline matrix tablets

\begin{tabular}{ccccc}
\hline Code & $\begin{array}{c}\text { Drug concentration } \\
\text { uniformity }(\%)\end{array}$ & $t_{50}(\mathrm{~h})$ & $t_{70}(\mathrm{~h})$ & $n$ \\
\hline F1 & 99.9 & 3.72 & 8.00 & 0.10 \\
F2 & 99.8 & 6.17 & - & 0.43 \\
F3 & 99.9 & 6.50 & - & 0.23 \\
F4 & 100.1 & 2.48 & 2.76 & 0.10 \\
F5 & 98.9 & 2.90 & 6.00 & 0.35 \\
F6 & 100.0 & 4.97 & 7.17 & 0.20 \\
F7 & 100.0 & 3.83 & 8.00 & 0.10 \\
F8 & 100.1 & 7.00 & - & 0.35 \\
F9 & 99.9 & 7.83 & - & 0.32 \\
F10 & 99.9 & 3.14 & 4.07 & 0.17 \\
F11 & 100.0 & 3.88 & 4.61 & 0.10 \\
F12 & 100.2 & 3.88 & 4.73 & 0.17 \\
F13 & 100.3 & 4.52 & 5.70 & 0.10 \\
F14 & 100.1 & 5.04 & 7.70 & 0.10 \\
F15 & 99.7 & 5.63 & 10.00 & 0.38 \\
F16 & 99.5 & 3.88 & 4.61 & 0.10 \\
F17 & 100.0 & 3.88 & 4.67 & 0.78 \\
F18 & 99.9 & 6.48 & 8.55 & 0.10 \\
\hline
\end{tabular}



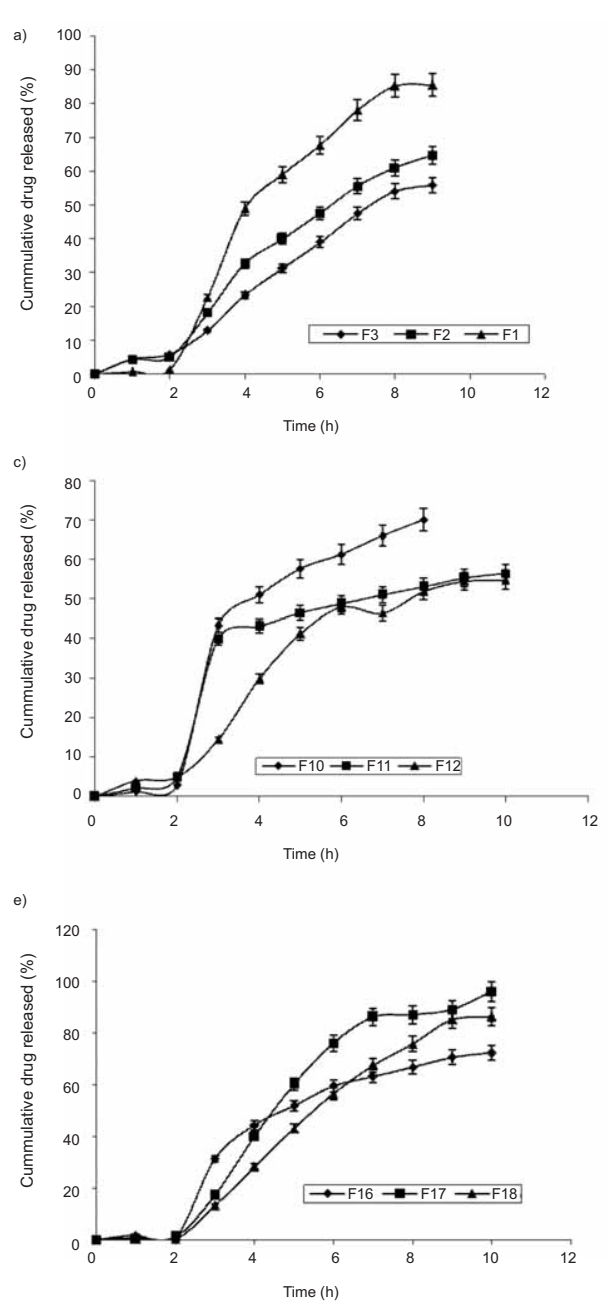
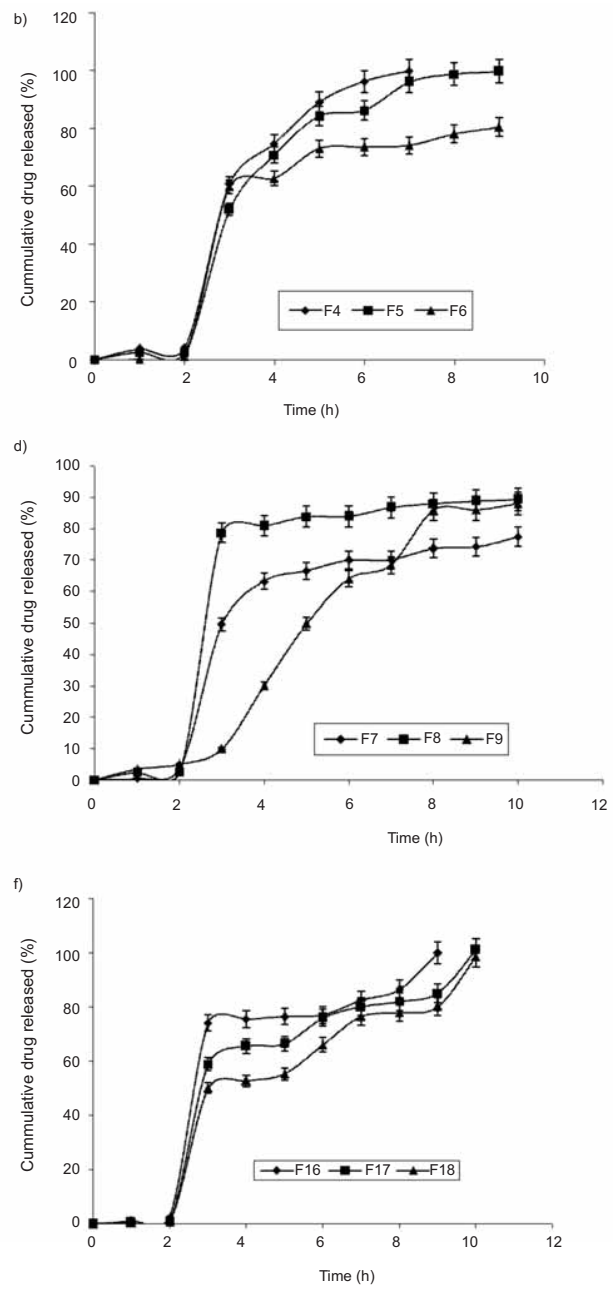

Fig. 1. In vitro release profile of theophylline from: a) Carbopol tablet matrices, b) ethylcellulose tablet matrices, c) sodium carboxymethylcellulose tablet matrices, d) Eudragit-coated tablet matrices containing binary mixtures of Carbopol and ethylcellulose at different ratios, e) Eudragit-coated tablet matrices containing binary mixtures of sodium carboxymethylcellulose and ethylcellulose at different ratios, f) Eudragit-coated tablet matrices containing binary mixtures of sodium carboxymethylcellulose and Carbopol at different ratios. Points represents mean \pm SD $(n=3)$.

tion of the polymer, with Carbopol exhibiting the greatest retardation effect (Table III), followed by EC and SCMC. Although the initial drug release from EC matrices (Fig. 2) was faster than the release from SCMC matrices (Fig. 3), the overall effect of retardation was greater in the former (Table III). This phenomenon, which was similarly reported in a 
previous study (14), is thought to be due to the fact that ethylcellulose, a water-insoluble polymer, when in contact with water, swells and retards drug release. It displays initial surface erosion, which is responsible for the initial fast release. The release rate then decreases because the external layers of the tablet become depleted and water must penetrate deeper layers of the tablet to reach the undissolved drug. This is probably responsible for a more extended $t_{70}$ in tablets containing EC (Table III). The concentration dependent decrease in drug release has been attributed to the differences in gel barrier generation speed as the tablets matrices contact with the dissolution medium. Increasing the polymer concentration leads to a gel viscosity increase and the active diffusion decrease, with dissolution speed decreasing (14). These tablet formulations, unlike the usual sustained release tablets with initial burst release during the first hour attributed to surface erosion of the matrix tablet prior to gel layer formation around the tablet core, did not exhibit this phenomenon. This is probably due to the acid-resistant coat provided by EUD. In acidic medium of the SGF, EUD is insoluble, thereby preventing any appreciable dissolution of matrix tablets. In the simulated intestinal fluid ( $\mathrm{pH}$ of 6.8), a rapid liberation of the drug was observed (Figs. 1a-f) in all the batches. This could be due to the fact that, at that alkaline $\mathrm{pH}$ an the EUD coat becoming soluble, the polymer complex might have become permeable and swellable (14). There was, however, a significant difference in the amount of drug released from the formulations containing single polymers and those containing blends. Fig. 1d illustrates that the blend of Carbopol and EC showed the lowest extent of drug release, followed by formulations containing carbopol alone. An explanation for this would be that in tablets containing a blend of Carbopol and EC, the drug became coated by an insoluble polymer complex, whereas in single polymer formulations, the drug which is embedded in the polymer matrix is exposed to the medium (14). The excessive viscosity and thickening property of Carbopol has also been implicated in its extensive retardant behavior (13). The significant decrease in drug release of batch F8 (containing $50 \%$ EC and $50 \%$ Carbopol) and F9 (containing $75 \%$ EC and $25 \%$ Carbopol) compared to batch F7 (containing $25 \%$ EC and $75 \%$ Carbopol) may be attributed to higher content of the hydrophobic component (EC) in batches F8 and F9. Similar behavior was noticed in formulations containing EC and SCMC (F13-F15) and Carbopol blended with SCMC (F16-F18).

In order to define the model that will represent the best fit for the formulations, dissolution data was analyzed using Peppas and Korsmeyer equation (15) given by:

$$
M_{\mathrm{t}} / M_{\mathrm{d}}=k t^{n}
$$

where $M_{\mathrm{t}}$ is the amount of drug released at time $t$, and $M_{\mathrm{d}}$ is the amount released at time $t=\infty, k$ is the kinetic constant, and $n$ is the diffusion exponent. The value of exponent $n$ was used to characterize the mechanism for both solvent penetration and drug release. The release exponent value is presented in Table III. It was found that neither polymer blending nor soaking in EUD dispersions altered the release mechanism from the tablets. However, linearity of the percentage the drug released vs. time plots (Figs. 1a-f) of all the tablet batches indicates that the drug release from the formulations did not follow a particular release mechanism. For example, the $n$ value for the formulation containing blends of Carbopol and SCMC (1:1) is 0.78, indicating an anomalous release mechanism, while all other formulations have the $n$ value lower than 0.5 , indicating Fickian release 
mechanism. Although diffusion predominates, solubility characteristics of the polymers and the drug as well as polymer erosion might have contributed to controlling the drug release profiles. This behavior commonly occurs in the matrix type pharmaceutical dosage forms where more than one transport mechanism is involved, such as erosion and swelling (14). On the basis of average or optimal values of $t_{50}$ and $t_{70}$, batch F15 (containing a blend of EC and SCMC at a ratio of 1:3) was considered to have performed better than single polymers. This batch was therefore chosen for in vivo studies in order to predict its plasma concentration-time profile in rabbits.

\section{Bioavailability in rabbits}

Results in Fig. 2 show that the mean plasma concentration of theophylline following oral administration to rabbits was higher for the formulated products than for the commercial tablets. Pharmacokinetic parameters for theophylline, such as the maximum plasma concentration, peak time and the area under the concentration-time curve, are listed in Table IV. The $t_{\max }$ of theophylline for the commercial tablets was $4.0 \mathrm{~h}$, which was faster than for the formulated tablets. The AUC of the formulated products, unlike $C_{\max }$, was significantly $(p<0.05)$ higher than those of the commercial tablets. The relative bioavailability of theophylline in the formulated tablets was about $36 \%$ higher than for the commercial tablets, indicating the feasibility of further development of an efficient oral delivery system. The plasma theophylline level peaked $8 \mathrm{~h}$ after oral administration of the formulation, and then slowly declined up to $24 \mathrm{~h}$. The AUC (0-24 h) and AUC $(0-\infty)$ were 405 and $415 \mu \mathrm{gL}^{-1} \mathrm{~h}^{-1}$, respectively, and were found to be significantly $(p<0.05)$ higher than the corresponding values $\left(296.10\right.$ and $297.10 \mu g \mathrm{~mL}^{-1} \mathrm{~h}^{-1}$, respectively) for the commercial product. Although it has been suggested that dissolution of tablets is almost always the rate-limiting step for intestinal absorption (16), this holds for well water soluble and permeable drugs. Dissolution of the drug from tablets controls the pharmacokinetics in case of drugs that fall under the biopharmaceutic classification system (BCS) 1 and 2; BCS 4 drugs possibly depend on dissolution and/or permeability constants. The slower dissolution conferred on the tablets by both the nature of the polymers and technology of formulation may have contributed to the extended AUC for TPH formulations. Although the formulated products had a significantly $(p<0.05)$ extended/improved $A U C$ and $t_{\max }$ values, the $C_{\max }$ value $\left(23.80 \pm 0.33 \mu \mathrm{g} \mathrm{mL}^{-1}\right)$ was not

Table IV. Pharmacokinetic parameters of theophylline after oral administration of formulated and commercial sustained release tablets to rabbits

\begin{tabular}{lcc}
\hline Pharmacokinetic parameters & Formulated SR theophylline tablet (F15) & Asmanyl® \\
\hline$C_{\max }\left(\mu \mathrm{g} \mathrm{mL}^{-1}\right)$ & $23.80 \pm 0.3$ & $24.40 \pm 0.3$ \\
$t_{\max }(\mathrm{h})$ & $8.00 \pm 3.4$ & $4.0 \pm 1.7$ \\
$t_{1 / 2}(\mathrm{~h})$ & $56.80 \pm 5.7$ & $5.97 \pm 2.2$ \\
$0-24$ AUC $\left(\mu \mathrm{g} \mathrm{mL}^{-1} \mathrm{~h}^{-1}\right)$ & $405.45 \pm 20.9$ & $296.10 \pm 18.8$ \\
$0-\infty$ AUC $\left(\mu \mathrm{g} \mathrm{mL}^{-1} \mathrm{~h}^{-1}\right)$ & $415.05 \pm 34.9$ & $297.10 \pm 28.9$ \\
Relative bioavailability $(\%)$ & $136.9 \%$ & $100 \%$ \\
\hline
\end{tabular}


M. Emeje et al.: Eudraginated polymer blends: A potential oral controlled drug delivery system for theophylline, Acta Pharm. 62 (2012) 71-82.

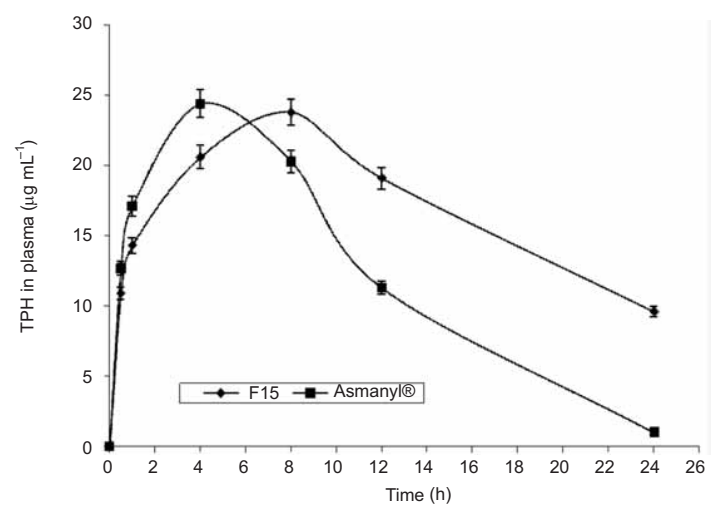

Fig. 2. Plasma concentration-time profiles of theophylline after oral administration of the formulated theophylline matrix tablet and the commercial tablet to rabbit $(n=5)$.

significantly different from that of the commercial product $\left(24.40 \pm 0.34 \mu \mathrm{g} \mathrm{mL}^{-1}\right)$. Polymer swelling and subsequent retardation of drug release from matrix tablets in the formulated products may also be implicated in extended oral bioavailability.

\section{CONCLUSIONS}

We have developed a tablet matrix system containing theophylline by using single and blends of hydrophobic and hydrophilic polymers and a modified coating technique using a minimal volume of Eudragit dispersion. The prepared theophylline tablets showed an increase in oral bioavailability of $36 \%$ compared to the commercial product. This study illustrates the potential usefulness of these polymers and the technology of preparation for sustained release of theophylline.

\section{REFERENCES}

1. S. Bose and H. Bogner, Solventless pharmaceutical coating processes: a review, Pharm. Dev. Technol. 12 (2007) 115-131; DOI: 10.1080/10837450701212479.

2. Z. Shao, L. Moralesi, S. Diaz and N. Muhammadi, Drug release from Kollicoat SR 30D-coated nonpareil beads: Evaluation of coating level, plasticizer type, and curing condition, AAPS PharmSciTech. 3 (2002) E15; DOI: 10.1208/pt030215.

3. A. Dashevsky, K. Kolter and R. Bodmeier, $\mathrm{pH}$-independent release of a basic drug from pellets coated with the extended release polymer dispersion Kollicoat SR $30 \mathrm{D}$ and the enteric polymer dispersion Kollicoat MAE 30 DP, Eur. J. Pharm. Biopharm. 58 (2004) 45-49; DOI: 10.1016/j.ejpb. 2004.03.013.

4. H. Alkhatib and A. Sakr, Optimization of methacrylic acid ester copolymers blends as controlled release coatings using response surface methodology, Pharm. Dev. Technol. 8 (2003) 87-96; DOI: $10.1081 /$ PDT-120017527. 
M. Emeje et al.: Eudraginated polymer blends: A potential oral controlled drug delivery system for theophylline, Acta Pharm. 62 (2012) 71-82.

5. N. Ebube and A. Jones, Sustained release of acetaminophen from heterogeneous mixture of two hydrophilic non-ionic cellulose ether polymers, Int. J. Pharm. 272 (2004) 19-27; DOI: 10.1016/ j.ijpharm.2003.11.020.

6. S. Conti, L. Maggi, L. Segale, E. OchoaMachiste, U. Conte, P. Grenier and G. Vergnault, Matrices containing NaCMC and HPMC 1. Dissolution performance characterization, Int. J. Pharm. 333 (2007) 136-142; DOI: 10.1016/j.ijpharm.2006.11.059.

7. M. Emeje and S. Ofoefule, Low level maize starch and sodium lauryl sulphate as release modifiers in Carbopol 941 capsule matrix, Int. J. Green Pharm. 3 (2009) 191-194.

8. S. Ofoefule and A. Chukwu, The effects of primogel on the release of frusemide from encapsulated granules, Acta Pharm. 50 (2000) 157-162.

9. P. Niculina, N. Ovidiu, P. Lenuta, E. Catalina and I. Marcel, Hydrogels based on chitosan-xanthan for controlled release of theophylline, J. Mater. Sci: Mater. Med. 21 (2009) 1241-1248; DOI: 10.1007/s10856-009-3937-4.

10. M. Emeje, Drug Delivery Using Blends of Natural, Semi-synthetic and Synthetic Polymers, PhD Thesis, University of Nigeria, Nsukka 2009.

11. M. O. Emeje, A. Izuka, C. Y. Isimi, S. I. Ofoefule and O. O. Kunle, Preparation and standardization of a herbal agent for the therapeutic management of asthma, Pharm. Dev. Tech. 16 (2011) 170-178; DOI: 10.3109/10837450903584910.

12. United States Pharmacopeia 26, National Formulary 21, USP Convention Asian Editor, Rockwille (MD) 2003.

13. M. Emeje, O. Olaleye, C. Isimi, J. Fortunak, S. Byrn, O. Kunle and S. Ofoefule, Oral sustained release tablets of zidovudine using binary blends of natural and synthetic polymers, Biol. Pharm. Bull. 33 (2010) 1561-1567.

14. M. Emeje, O. Kunle and S. Ofoefule, Effect of the molecular size of carboxymethylcellulose and some polymers on the sustained release of theophylline from a hydrophilic matrix, Acta Pharm. 56 (2006) 325-335.

15. R. Korsmeyer, R. Gunny E. Doelker P. Buri and N. Peppas, Mechanism of solute release from porous hydrophilic polymers, Int. J. Pharm. 15 (1983) 23-35; DOI: 10.1016/0378-5173(83)90064-9.

16. B. Lee, M. Kang, W. Choi, Y. Choi, H. Kim, S. Lee, J. Lee and Y. Choi, Solubilized formulation of olmesartan medoxomil for enhancing oral bioavailability, Arch. Pharm. Res. 32 (2009) 1629-1635; DOI: $10.1007 /$ s12272-009-2117-x.

\section{$S A \check{Z} E T A K$}

\section{Polimerne mješavine obložene Eudragitom: Potencijalni sustav za kontroliranu peroralnu isporuku teofilina}

MARTINS EMEJE, LUCY JOHN-AFRICA, YETUNDE ISIMI, OLOBAYO KUNLE i SABINUS OFOEFULE

Pripravci za produljeno oslobađanje (SR) omogućavaju produljeno i kontinuirano oslobađanje lijeka u gastrointestinalnom (GI) traktu i poboljšavaju bioraspoloživost lijekova s uskim apsorpcijskim prozorom. U radu se predlaže nova strategija za razvoj formulacija s produljenim oslobađanjem teofilina (TPH), koja se temelji na sustavu za produljeno oslobađanje, kojem je u svrhu produljenja vremena oslobađanja modificiran način oblaganja i bubrenja. Korišteni su različiti polimeri, kao što su Carbopol 71G (CP), natrijeva karboksimetilceluloza (SCMC), etilceluloza (EC) i njihove kombinacije. Priprav- 
M. Emeje et al.: Eudraginated polymer blends: A potential oral controlled drug delivery system for theophylline, Acta Pharm. 62 (2012) 71-82.

ljene matriks tablete obložene su 5-postotnom $(\mathrm{m} / \mathrm{m})$ disperzijom Eudragita (EUD) kako bi se postiglo produljeno oslobađanje tijekom $24 \mathrm{~h}$. U pripravljenim formulacijama određena je koncentracija lijeka i in vitro oslobađanje. Rezultati pokazuju da se povećanjem udjela polimera smanjuje brzina oslobađanja in vitro. Oblaganje s EUD značajno je produljilo lag fazu tijekom prva 2 sata otapanja u kiselom $\mathrm{pH}$ simuliranog želučanog soka (SGF). Naime, oblaganje usporava ulazak vode i tako smanjuje pogonsku silu za oslobađanje lijeka. Zbog povećane topljivosti obložnog sloja i matriksa u lužnatom mediju, oslobađanje u simuliranoj intestinalnoj tekućini (SIF) je brže. Optimizirana formulacija ispitana je in vivo na zečevima. Farmakokinetički parametri novih formulacija uspoređivani su s komercijalnim pripravkom Asmanyl ${ }^{\circledR}$. Asmanyl ${ }^{\circledR}$ tablete pokazuju bržu apsorpciju $\left(t_{\max } 4,0 \mathrm{~h}\right) \mathrm{u}$ odnosu na TPH formulaciju $\left(t_{\max } 8,0 \mathrm{~h}\right) \cdot c_{\max }$ i $A U C$ vrijednosti TPH formulacije bile su značajno $(p<0,05)$ više od onih za Asmanyl ${ }^{\circledR}$, što ukazuje na relativnu bioraspoloživost od oko 136,93 \%. Stoga smatramo da su polimeri obloženi eudragitom potencijalno korisni za oralnu upotrebu teško topljivog lijeka teofilina.

Ključne riječi: teofilin, polimerne mješavine, modificirano oslobađanje, in vitro oslobađanje, in vivo oslobađanje

Department of Pharmaceutical Technology and Raw Materials Development, National Institute for Pharmaceutical Research and Development (NIPRD), Abuja, Nigeria

Department of Pharmacology and Toxicology, National Institute for Pharmaceutical Research and Development (NIPRD), Abuja, Nigeria

Department of Pharmaceutical Technology and Industrial Pharmacy, University of Nigeria, Nsukka, Enugu state, Nigeria 